\title{
A Cost and Returns Evaluation of Alternative Dairy Products to Determine Capital Investment and Operational Feasibility of a Small-Scale Dairy Processing Facility ${ }^{1}$
}

\author{
K. M. Becker, ${ }^{\star 2}$ R. L. Parsons, ${ }^{\star}$ J. Kolodinsky, ${ }^{*}$ and G. N. Matiru† \\ *Department of Community Development and Applied Economics, University of Vermont, Burlington 05405 \\ †Independent Research Consultant, Williston, VT 05495
}

\section{ABSTRACT}

This study examines the economic feasibility of 50and 500-cow dairy processing facilities for fluid milk, yogurt, and cheese. Net present value and internal rate of return calculations for projected costs and returns over a 10 -yr period indicate that larger yogurt and cheese processing plants offer the most profitable prospects, whereas a smaller yogurt plant would break even. A smaller cheese plant would have insufficient returns to cover the cost of capital, and fluid milk processing at either scale is economically infeasible. Economic success in processing is greatly contingent upon individual business, financial management, and marketing skills.

Key words: small-scale dairy processing, yogurt, cheese, fluid milk

\section{INTRODUCTION}

Farm gate milk prices have become increasingly volatile since the late $1980 \mathrm{~s}$. With every decline in price, a subset of producers expresses the desire to set up their own processing facilities to capture the so-called intermediary profits. In 2002 , farm gate milk prices hit a 25 -yr low whereas retail prices only showed a slight decline. This raised the ire of many dairy farmers and led to a group of them in northeastern Vermont to seek assistance in determining the feasibility of establishing a milk processing facility that might provide them with a greater financial return and more market security.

The group of farmers met with elected officials in the town of Westfield, and the town secured a Vermont Community Development Planning Grant to investigate the economic feasibility of constructing and op-

Received July 6, 2006.

Accepted December 8, 2006.

${ }^{1}$ This study was conducted on behalf of the town of Westfield, Vermont, through a grant provided by the Vermont Agency of Commerce and Community Development [Grant \#0161/98PG(13)].

${ }^{2}$ Corresponding author: Kenneth.Becker@uvm.edu erating a plant for processing dairy products. The town in turn contracted the Department of Community Development and Applied Economics at the University of Vermont to conduct a feasibility study to determine the scale and type of processing plant that could provide long-term price enhancement for participating dairy farmers. After consultations with the farmers, a decision was made to limit the study to 3 dairy productsfluid milk, yogurt, and cheese.

The study's goal was to determine the capital requirements, operating costs, and projected returns from 2 scales of processing plants for each of the dairy products. The smaller scale would handle milk produced by 50 cows (equivalent to 1 dairy farm), and the larger scale would receive milk from 500 cows (or 5 averagesized local dairy farms). To determine profitability, we calculated net present value (NPV) and internal rate of return (IRR) for each of the proposed processing facilities based on an initial investment in land, buildings, and equipment, projected operational costs, and estimated annual gross revenues (cash flow) over a 10yr period.

The primary force driving this study was the lack of any models, designs, or research on small-scale dairy processing facilities. Although studies on large-scale fluid milk processing exist (Erba et al., 1997), the size difference makes their cost structure and returns incomparable to the small scale of plants under consideration. For example, Howick et al. (1993) examined the viability of a fluid milk plant in Maine. Their study looked only at fluid milk and was designed to "provide the lowest achievable costs of processing and distributing milk in Maine." The model plant considered processed an average weekly volume of 456,240 gallons of milk, equivalent to weekly milk production of 3.9 million pounds, which is much greater than the weekly production of 161,000 and 17,500 pounds that would be processed in our study's largest and smallest facilities, respectively. When Howick et al. (1993) evaluated a plant $150 \%$ bigger than their model, they determined that "economies of scale generate processing cost reduc- 
Table 1. Sales output for Vermont dairy manufacturers by category in 2002

\begin{tabular}{lc}
\hline Dairy product category & $\begin{array}{c}\text { Annual sales volume } \\
\text { (millions of dollars) }\end{array}$ \\
\hline Fluid milk & 222 \\
Cheese & 208 \\
Condensed and evaporated milk & 188 \\
Ice cream, frozen dessert, cultured yogurt & 130 \\
\hline
\end{tabular}

tions between $7 \%$ and 13\%." In a later study, Erba et al. (1997) looked at plant and labor costs for 35 medium and large fluid milk plants in 15 states. Their analysis found that the factors that had greatest direct impact on costs were labor, size of plant, plant capacity utilization, level of technology in processing, filling, cooling, and loading areas, and the type of ownership. Supermarketowned plants had $15 \%$ lower cost per gallon than either proprietary or cooperatively owned plants (Erba et al., 1997). The plants modeled in our study are much smaller in comparison and lack the economies of scale associated with cost reduction benefits indicated in these earlier studies.

More recently, researchers at the University of $\mathrm{Ne}-$ braska examined the feasibility of processing specialty cheeses (Food Processing Center, 2002). This study looked at the investment costs for setting up cheese plants with volumes ranging from 4,000 to 32,000 gallons of raw milk per week. The research did not examine operating costs for the plants and only looked at onfarm specialty cheeses. In addition, the study did not explicitly take into account the cost of equipment and building space for either a receiving bay or for cold storage and warehousing, nor did it include clean-inplace cleaning systems for most of the plant models.

Historically, a wide range of dairy products has been produced in Vermont. Because the state has traditionally served as the milk-shed for southern New England, and has a relatively low population, Vermont milk has to be transported quickly to metropolitan markets for fluid use or transformed into storable products within the state or at plants in neighboring states. According to the New England Agricultural Statistics Service (NEAS, 2002), the annual farm gate value of Vermontproduced raw milk was about $\$ 400$ million in 2002 . In contrast, there are about 45 plants processing valueadded dairy products within the state with sales totaling $\$ 748$ million, primarily from cheese and fluid milk as summarized in Table 1 (USDA, 2004; B. Moyer, Vermont Agency of Agriculture, Food, and Markets, Montpelier, VT; personal communication, July 2003).

In spite of this longstanding history of dairy processing, Vermont's industry looks very different from
Table 2. Change in number of Vermont dairy processing plants from 1985 to 2003

\begin{tabular}{lcc}
\hline Dairy product category & 1985 & 2003 \\
\hline Fluid milk & 11 & 4 \\
Cheese & 16 & 38 \\
Soft products (ice cream, yogurt) & 3 & 4 \\
Whey and dry powder & 2 & 3 \\
\hline
\end{tabular}

how it did 2 decades ago (Table 2). Compared with 1985, there are many fewer fluid milk processing plants operating in the state and more specialty cheese companies (B. Moyer, Vermont Agency of Agriculture, Food, and Markets, Montpelier, VT; personal communication, July 2003). The market demand for specialty cheeses as well as the creativity and skill of Vermont cheese makers has enabled this segment of the dairy industry to increase dramatically, with nearly two and one-half times as many plants in operation in 2003 as there were in 1985. Many of these processing facilities are on-farm. However, just 4 of these plants accounted for more than $95 \%$ of all the milk processed into cheese in Vermont (B. Moyer, Vermont Agency of Agriculture, Food, and Markets, Montpelier, VT; personal communication, July 2003).

This study presents a generalized estimate of the capital investment, operational costs, and potential returns from small-scale processing plants for fluid milk, cheese, or yogurt using raw milk from 50 cows ( 1 dairy farm) and 500 cows (equivalent to 5 small dairy farms). Profitability of each of the plants is then compared using the IRR and NPV measures.

\section{MATERIALS AND METHODS}

Profitability analysis for processing plants for fluid milk, cheese, and yogurt of the scale proposed by dairy farmers in Westfield, Vermont, was based on costs and returns data obtained from dairy industry experts in Vermont. We developed budgets on electronic spreadsheets for facility construction, operation, and economic feasibility assessment for fluid milk, yogurt, and cheese produced on the 2 different sized plants. A number of assumptions were made with respect to the time frame, the types of dairy product categories, whether the facility would be a retrofit of an existing building or new construction, and whether used or new equipment would be purchased. Depending on the level of "do-ityourself" expertise, availability of existing space and used equipment, and the creativity and ingenuity of a plant owner/operator, significant facility construction and equipment installation costs could be deducted from the budgeted plant models. All plant sizes and product possibilities relied on the same set of construc- 
Table 3. Size for processing plant facility areas

\begin{tabular}{lr}
\hline & Area $\left(\mathrm{ft}^{2}\right)$ \\
\cline { 2 - 2 } Facility & $\begin{array}{c}\text { Milk from } \\
1 \text { farm }\end{array}$ \\
\hline Raw milk receiving: dock and storage tanks & 5 farms \\
Dry storage: warehouse and dock & 1,200 \\
Refrigerated storage: cooler and loading dock & 800 \\
Office area & 1,200 \\
Processing floor: storage tanks, pasteurizer, cream separator, cheese/yogurt vats, filling/packing line & 1,000 \\
Miscellaneous: aisles, storage, expansion, overhead & 2,500 \\
Total area & 1,2000 \\
\hline
\end{tabular}

tion and equipment cost assumptions. Industry experts reviewed model projections to ascertain their validity. The assumptions of this study were made due to the unknowns for such an enterprise regarding the specifics of ownership, financing arrangement, management skills, production technologies, marketing strategies, plant location, initial production volume, and allowances to expand future capacity. These assumptions were necessary to develop the operating cost and return analysis; hence, the subsequent study recommendations. Significant variation from these assumptions could dramatically alter the results.

\section{Model Plant Sizes}

The 2 model plant sizes under consideration were a plant with an approximate capacity for milk produced by a single family-owned farm (50 cows), and one with a capacity for milk from 5 average-sized dairy farms (500 cows) within the state of Vermont. The 50-cow herd was assumed to produce approximately 18,250 pounds of milk per cow per year $(912,500$ pounds per year for 50 cows), or an initial volume of 17,500 pounds of milk per week for processing. The second plant size production volume assumed the statewide herd size of 96 and production per cow of 17,431 pounds of milk sold per cow as reported by NEAS (2002). Assuming 5 farmers of this average size, the plant would receive 161,000 pounds of milk per week (8.4 million pounds per year) for processing. Over a 10 -yr period, production levels and annual sales were assumed to grow at the rate of $15 \%$ per year. These basic assumptions were used to analyze alternative plant scenarios for the 3 different dairy product possibilities.

\section{Start-Up Investment Cost}

Start-up investment cost for each of the model plant facilities would include land, buildings, site work, utilities, and equipment. Buildings would include the processing plant (processing space, water supply, drainage and utility connections for processing equipment), office space, milk truck delivery bay, finished product cold storage, dry product warehouse space (a storage area for labels, containers, detergents, etc.), wastewater treatment capacity, and shipping/loading dock area. Table 3 shows the square footage deemed necessary for each of the plant facility areas. The costs of each aspect of the facility, fixtures, and equipment constituted the overall start-up costs for each of the model plant facilities. These initial investment costs $\left(\right.$ per $\left.\mathrm{ft}^{2}\right)$ are summarized in Table 4.

Initial start-up investment costs are integral to the NPV calculations used in the capital investment analysis section that follows. Furthermore, the initial investment amount is the basis on which annual fixed costs of ownership are calculated. These include annual depreciation, interest, real estate taxes, and property insurance. Specifically, economic choices directly affect initial asset cost, its expected useful life and salvage value, the cost of capital to finance asset acquisition, and the annual operating and maintenance costs. The associated facts and assumptions regarding these economic considerations have direct effects on engineering decisions such as whether to buy new or reconditioned equipment and whether to retrofit an existing facility or break ground and build a new plant.

Engineering information for equipment needs was obtained from a survey of regional equipment dealers and discussions with Vermont dairy industry experts knowledgeable of dairy processing equipment needs, availability, and prices. Final results of the engineering specifications were reviewed by dairy industry processing experts who ascertained their validity in being representative of actual industry characteristics and costs. Total cost for plant construction for facilities processing milk from 1 farm and 5 farms are provided in Table 5, with a detailed itemized listing of the equipment and prices provided in Table A1.

To make accurate comparisons between alternative plants, all models were assumed to purchase land and construct the building reflecting a true ownership cost for the assets. These costs are presented in Table 6 . Average cost per square foot was estimated and ad- 
Table 4. Plant construction costs (per $\mathrm{ft}^{2}$ )

\begin{tabular}{lr}
\hline Construction category & ${\text { Cost, } \$ / \mathrm{ft}^{2}}^{2}$ \\
\hline Site and general construction (includes paving and landscaping) & 7.20 \\
Mechanical, electrical, HVAC & 16.50 \\
Pre-engineered steel building, clear span, colored roofing/siding $30^{\prime}$ to $40^{\prime}$ wide; $20^{\prime}$ eaves height & 18.25 \\
Contingency (conceptual stage) & $20 \%$ project \\
Project staff/management: architectural, engineering, field office, clean-up, permits & $20 \%$ project \\
Total & 58.75 \\
\hline
\end{tabular}

justed for geographic location using RSMeans Building Construction Cost Data (Waier, 2002). According to the Northern Vermont Development Authority, the cost of 2 to 3 acres of land in an Orleans County, Vermont industrial park (properly zoned and with necessary access to suitable utility and entrance roads) averages between $\$ 25,000$ and $\$ 35,000$ per acre (S. Patterson, Northern Vermont Development Association, Newport, VT; personal communication, September 2003).

When considering whether to build new or to retrofit an existing facility, air quality and other potential contamination concerns have to be taken into account. This is especially true when locating a small processing plant on a dairy farm for cheese or for curing any type of aged products. Contamination of the aged cheese from mold spores, dust, manure, odors, or other contaminants would pose significant obstacles to producing consistently high quality and hygienic dairy products. One possible solution would be to install a constantly pressurized air filtration system, although the cost of such a mechanical system might render the whole processing plant unprofitable (B. Moyer, Vermont Agency of Agriculture, Food, and Markets, Montpelier, VT; personal communication, July 2003).

\section{Facility and Equipment Investment Cost Summary}

As shown in Table 6, the estimated land acquisition, facility construction, and equipment purchase and installation cost for a small-scale dairy processing plant is between $\$ 1.3$ and $\$ 1.8$ million. There is little difference in equipment cost between the 2 plant sizes, or the 3 different product categories. This is because the

Table 5. Plant facility construction costs (in $\$$, rounded to nearest $\$ 10,000)$

\begin{tabular}{lcc}
\hline & \multicolumn{2}{c}{ Plant capacity } \\
\cline { 2 - 3 } & $\begin{array}{c}\text { Milk from } \\
1 \text { farm }\end{array}$ & $\begin{array}{c}\text { Milk from } \\
5 \text { farms }\end{array}$ \\
\hline Well, septic, $\$$ & 25,000 & 25,000 \\
Walk-in cooler/loading dock, $\$$ & 13,000 & 22,500 \\
Cost per $\mathrm{ft}^{2}, \$$ & 58.75 & 58.75 \\
Total square footage, $\mathrm{ft}^{2}$ & 7,000 & 15,400 \\
Total cost for facility construction, $\$$ & 450,000 & 950,000 \\
\hline
\end{tabular}

plant sizes proposed are so similar that recommended sizes for tanks, pumps, lines, and production equipment are nearly identical. Similarly, cost of equipment for production of cheese and yogurt, or for fluid milk bottling are also nearly identical at this scale. The key differences between the 2 plant sizes are additional warehouse space and room for growth in the larger of the 2 facilities. For both plants, a larger volume of production resulting from 15\% annual growth may require more operating shifts per week; however, the same basic set of equipment would be required initially.

\section{Operating Costs and Returns Analysis}

Realistic forecasting of revenues and costs of valueadded dairy production requires estimates and assumptions in many areas, including market demand for products, productive capacity of the plant, labor costs and efficiency, electricity and fuel costs and requirements, water supplies and wastewater disposal costs, seasonality of production and demand, market prices for raw milk, and potential premiums above federal minimum requirements that may be paid to farmers. The most significant costs, in terms of their percentage of total cost of goods sold, were determined at the outset to be labor, raw milk prices, factory overhead (depreciation, maintenance, insurance, etc.), and interest expenses. Consequently, the greatest attention has been paid to these cost items. Financial costs and returns were also compared with aggregate results for dairy processing firms based on the North American Industry Classification System (NAISC) codes 311500 and Standard Industry Codes (SIC) 2022 and 2026 (Risk Management Association, 2001; Dunn and Bradstreet, 2002). Cash

Table 6. Estimated plant and equipment investment costs (\$)

\begin{tabular}{lrr}
\hline & \multicolumn{2}{c}{ Plant capacity } \\
\cline { 2 - 3 } & Milk from & Milk from \\
& 1 farm & 5 farms \\
\hline Land & 65,000 & 65,000 \\
Facility & 450,000 & 950,000 \\
Equipment & 765,000 & 765,000 \\
Total investment cost & $1,280,000$ & $1,780,000$ \\
\hline
\end{tabular}


Table 7. Retail dairy product price survey, Burlington, Vermont, July 2003

\begin{tabular}{lcc}
\hline Product & $\begin{array}{c}\text { Retail } \\
\text { price } \\
\text { range, } \$\end{array}$ & $\begin{array}{c}\text { Imputed wholesale } \\
\text { price for study } \\
\text { calculations, } \$\end{array}$ \\
\hline Fluid milk, gallons & $2.69-2.89$ & 2.25 per gallon \\
Heavy cream, 1 quart & $1.89-2.09$ & 1.50 per quart \\
Yogurt, 1 quart & $1.99-2.39$ & 1.75 per quart \\
Cheese, 1 pound block & $5.25-8.50$ & 5.50 per pound \\
\hline
\end{tabular}

flow summaries for each plant type are compiled in Table A2.

Revenue Forecasting. Estimating revenues for the 3 products (fluid, yogurt, and cheese) required a projection of sales volume by year, taking into account business growth assumptions over time, multiplied by a sales price per unit of product. Dairy products-even processed or value-added products-are part of a highly competitive industry. Product prices can range from a low end for generic products to the high end for premium quality from established brand name companies. Given the marketing hurdles for a start-up company together with the purchasing power of the likely consumer market in which these products would initially be introduced, wholesale prices gathered from regional distributors in the midrange for the 3 product types were used in this study (Table 7).

The median retail price for each product was multiplied by 0.80 to impute wholesale prices used for this study. Product prices were inflated $2 \%$ per year; approximately equal to one-half of the annual change in the food and beverage index for all items over the previous $10 \mathrm{yr}$.

Labor. According to a 1997 study of labor productivity and costs in fluid milk plants throughout the United States, "cost of labor represented the largest category of (variable) plant cost per gallon, accounting for about $58 \%$ of the total" (Erba et al., 1997). The pay rates for positions within the dairy processing plant were derived from the Vermont Department of Employment and Training (2003) labor statistics (Table 8). The number of employees, by classification, was determined after consultation with dairy industry experts. The study assumes no unpaid operator or family labor.

Farm Milk Prices. The Agricultural Marketing Service of the USDA calculates and announces a monthly statistical uniform price (SUP) for milk through the office of the Market Administrator of the Federal Milk Marketing Order Number 1, Northeast Marketing Area (2003). The monthly SUP is an aggregate of the minimum class prices processors must pay to farmers pursuant to federal regulation, multiplied by the pounds of milk sold within the marketing area for each of 4 classes of milk product. If an individual family is processing its own milk, it should attempt to gain a price at least equal to the Federal Milk Order minimum price. If 5 farms are operating a processing plant together, the plant is legally required to pay each farm the Federal Milk Order minimum price. To determine the price for raw milk used in the model plants, this study used the mean average price from January 2000 through May 2003 for Class I (fluid milk products), Class II (soft dairy products), and Class III (cheese products) as published by Federal Milk Order Number 1. Respective average class prices and SUP are summarized in Table A3.

Interest Expenses and Inflation. Operating and maintenance costs are adjusted annually using the mean inflation rate from the Consumer Price Index (mean CPI All Items Index) over the previous $10 \mathrm{yr}$ as reported by the US Department of Labor (2003). Interest rates for borrowed capital (and the projected annual interest costs) were calculated as the mean of prime rate as reported by the Federal Reserve Banks' Economic Research Office plus 200 basis points, and the current interest rate being charged to agricultural borrowers by the Vermont Agricultural Credit Corporation (VACC) as of July 2003 (Federal Reserve Bank of St. Louis, 2003; S. Isham, VACC, Montpelier, VT; personal communication, July 2003).

Annual financial projections for each of the 3 dairy product types were assumed to be based on capital investments financed $50 \%$ by equity and $50 \%$ by debt, with the debt portion being obtained half through a

Table 8. Employee classification and pay rates

\begin{tabular}{|c|c|c|}
\hline Classification & Typical position titles & $\begin{array}{c}\text { Average } \\
\text { annual pay } \\
\text { rate, } \$\end{array}$ \\
\hline Class 1 & Janitor/cargo agent (shipping/dock worker) & 17,100 \\
\hline Class 2 & Secretary/bookkeeper & 22,500 \\
\hline Class 3 & Packaging/filling machine operators & 20,000 \\
\hline Class 4 & Food batch maker (set up and operate mixing/blending equipment) & 24,000 \\
\hline Class 5 & Cheese maker/yogurt maker & 50,000 \\
\hline Class 6 & Truck drivers/delivery services & 25,000 \\
\hline Class 7 & Management (production, marketing, business) & 60,000 \\
\hline
\end{tabular}


Table 9. Interest and inflation rates (in percentage)

\begin{tabular}{lc}
\hline Benchmark & Rate (\%) \\
\hline Consumer Price Index (All Items Index, 1993-2002, 10-yr average) & 4.1 \\
Commercial prime rate (July 2003) plus 200 basis points & 6.22 \\
Vermont Agricultural Credit Corporation (July 2003) & 5.25 \\
Blended interest cost on borrowed funds & 5.735 \\
Discount rate used in net present value calculations & 8.00 \\
\hline
\end{tabular}

commercial bank loan and half through a loan from VACC (Table 9). The VACC generally charges slightly lower interest rates than commercial lenders to induce economic development in the agricultural sector. Interest cost calculations are based on loan terms that include a 10-yr amortization of principal, consistent with the 10 -yr period under investigation.

\section{Summary of Key Assumptions Used in Cash Flow Projections}

Cash flow projections for each of the plants are shown in Appendix B. These projections are based on consultations with key industry experts. The projections reflect conservative cash flow estimates making them realistic and achievable. It is assumed that each facility will use knowledgeable marketers and nimble managers so that sales growth (product volume) of $15 \%$ per year can be maintained, overhead costs can be controlled, and efficiencies in cost of goods sold can be attained. No special price premiums attributable to organic labeling, highend specialty cheese manufacturing or other bonuses have been assumed. Product pricing is based on average prices for good quality dairy products, rather than a premium pricing strategy. Direct costs are projected to grow at an annual rate of $15 \%$ per year, in line with $15 \%$ growth in sales volume. Indirect costs (general, administrative, marketing, and factory overhead) are projected to grow at $4 \%$ per year, comparable to the mean CPI All Items Index. Product prices are projected to grow $2 \%$ per year, or half the 10-yr CPI Food and Beverage Index (assuming retailers capture the other half).

The average cost of wastewater disposal is estimated to be between $\$ 5$ and $\$ 7 / 1,000$ gallons of wastewater. A rule of thumb for wastewater volume in dairy plants is that for every 2 gallons of milk processed, 1 gallon of wastewater is generated (J. Jewett, Vermont Agency of Natural Resources, Montpelier, VT; personal communication, August 2003). These values are reported to be reasonably consistent regardless of the disposal method.

No increase in raw milk prices was assumed during the period evaluated given the historic level of farm milk price volatility. All plants would be assumed to pay the SUP except the 5-farm fluid plant, which due to its volume, would be required to pay into the Federal Milk Marketing Order's producer settlement fund as a Class I fluid manufacturer, effectively causing the plant to pay Class I prices, even though farmers supplying the plant would receive SUP level prices. The 5-farm yogurt and cheese plant scenarios predict a $\$ 1 /$ cwt price premium to farmers, which is included in the cash flow projections.

\section{Capital Investment Analysis}

NPV. Net present value calculations were used to compare profitability for the alternative processing facilities. The present value (PV) of future earnings takes into account the future stream of annual cash benefits (revenues) minus the future stream of annual cash costs (cost of goods sold, operating expenses, and interest payments) discounted for the time value of money. The PV equation is:

$$
P V=A\left[\frac{(1+i)^{n}-1}{i(1+i)^{n}}\right]
$$

where $\mathrm{A}$ is the annuity amount, $i$ is the interest rate, and $n$ is the number of periods (years) over which the annuity is discounted (Adelman and Marks, 2001). The NPV calculations rely on the initial investment costs determined for each plant type from the economic-engineering assessment paid out at time period zero (present value of costs), and the stream of annual cash flows from the operating costs and returns assessment over a defined number of time periods into the future at a specified discount rate (present value of benefits). This study used a 10-yr period and an 8\% discount rate across all plant possibilities.

IRR. The typical start-up business does not experience mathematically convenient timing of receipts and expenditures, nor are such financial transactions stable and regularly predictable. As such, time value of money calculations can become increasingly complex to estimate, perform, and interpret (Hayes, 2002). Internal rate of return calculations offer alternative profitability assessment for time value of money calculations that help to determine the actual rate of return on a particu- 
Table 10. Net present value (NPV) and internal rate of return (IRR) summary

\begin{tabular}{lcc}
\hline Plant type/milk volume & NPV, $\$$ & IRR, \% \\
\hline Fluid milk plant & & \\
Capacity for 1 farm & $(2,801,750)$ & $\mathrm{NMF}^{1}$ \\
Capacity for 5 farms & $(2,274,891)$ & -8.3 \\
Yogurt plant & $(156,906)$ & 6.4 \\
Capacity for 1 farm & $1,072,476$ & 13.8 \\
Capacity for 5 farms & $(532,668)$ & 2.7 \\
Cheese plant & 966,214 & 13.9 \\
Capacity for 1 farm & & \\
Capacity for 5 farms & & \\
\hline
\end{tabular}

${ }^{1} \mathrm{NMF}=$ no meaningful figure.

lar investment given unequal cash inflows and outflows. Internal rate of return is defined as the discount rate at which the NPV of an investment equals zero (Hayes, 2002). Calculations were performed using Microsoft Excel software. According to capital budgeting principles, when the IRR is greater than the opportunity cost (the expected return on a comparable investment) of the capital required, the investment under consideration may be undertaken. The IRR of an investment in a dairy processing facility should be high enough to provide owners and investors a rate of return sufficient to reward them for the risk inherent in such an undertaking.

\section{RESULTS AND DISCUSSION}

This study provides a template of the data needed to make capital investment decisions, and a forecasting model of production levels, income streams, and expense relationships by various plant sizes and dairy product categories. Results of capital investment analysis are summarized in Table 10. Three model plant types (fluid, yogurt, and cheese) were compared using 2 different sizes for each plant type, processing the milk from 1 farm and from 5 farms. The scale of these results indicates that relaxing any of the basic assumptions would not alter the findings.

Both fluid milk plants had substantially negative NPV. Based on the historical evidence of Vermont's dairy industry over the past 2 decades, these results are not surprising. Fluid milk plants have closed due to inefficient economies of scale, and because the product-beverage milk-is essentially an indistinguishable commodity. It is very difficult for a processor to position a fluid brand to strategic advantage. The exceptions seem to prove the rule. Of the 4 remaining fluid milk-processing facilities in Vermont, the only one that began operations within the past $20 \mathrm{yr}$ is an organic product sold in glass bottles. Two of the other 3 are closely held, multigenerational, family businesses with strong loyalty within small, and clearly defined geographic distribution areas. The fourth and final plant has similar characteristics. Although a regional powerhouse now owns it, both its trade-name brands are strongly identified within the geographic region served by the plant.

Both yogurt plants have positive NPV and the larger yogurt plant has a favorable IRR. The smallest-scale yogurt plant shows an IRR of $6.4 \%$, slightly under the $8 \%$ discount rate used to analyze these capital investments. It fares better than the small-scale cheese plant, presumably because of a more favorable conversion rate from raw milk into saleable product (1:1 vs. 10:1). Increasing the size of the yogurt plant is predicted to yield greater returns both to owners and managers as well as the farmers supplying the milk.

The small-scale cheese plant has a negative NPV with an IRR of $2.7 \%$. This would not be a viable economic undertaking. The larger cheese plant has a positive NPV and IRR. This plant indicates a greater likelihood of economic viability and the ability to generate profits. The results of this study show that the smallest scale cheese plant remains an economic challenge. With an IRR less than 3\%, a single-farm cheese plant does not return enough profit to cover the operation's cost of capital. Such operators must rely on a premium pricing strategy, the highest quality product, and strong marketing and distribution efforts to succeed.

Again, based on recent historical evidence in Vermont, cheese plants and other dairy processors (primarily ice cream and yogurt) have increased in healthy numbers over the last $20 \mathrm{yr}$. In both of these 5 -farm scenarios, the yogurt plant and the cheese plant are predicted to pay a $\$ 1 /$ cwt premium to supplying farmers while being able to generate favorable IRR for owners. Nevertheless, these projections are subject to a number of variables that affect the range of possible outcomes for each plant. A sensitivity analysis of the variables provides a way to judge the relative risks that exist.

\section{Sensitivity Analysis}

Projecting budgets over a 10 -yr period is an inexact science. There are a wide range of variables both within and outside the control of management that can have serious negative impacts on future earnings and line item costs associated with production and marketing efforts. Accordingly, projections and forecasting are not complete without testing the uncertainty that accompanies normal business operations, and an analysis is warranted to determine the effects that price declines or cost increases might have on financial projections (Kohl, 1992). Such a sensitivity analysis on the financial performance for the various plant sizes in this study provides a way to judge the revenue and expense risks 
Table 11. Sensitivity analysis for changes in revenue and expenses and effects on break-even product prices and raw milk costs for various dairy plant sizes and types

\begin{tabular}{|c|c|c|c|c|}
\hline Plant description & $\begin{array}{l}\text { Change in } \\
\text { revenue to } \\
\text { break even }\end{array}$ & $\begin{array}{l}\text { Wholesale } \\
\text { product price } \\
\text { if revenue } \\
\text { adjusted to } \\
\text { break-even } \\
\text { point }\end{array}$ & $\begin{array}{l}\text { Change in } \\
\text { expenses to } \\
\text { break even }\end{array}$ & $\begin{array}{c}\text { Raw milk } \\
\text { cost if } \\
\text { expenses } \\
\text { adjusted to } \\
\text { break even, } \\
\$ / \text { cwt }\end{array}$ \\
\hline \multicolumn{5}{|c|}{ Sensitivity analysis } \\
\hline \multicolumn{5}{|l|}{ Fluid milk } \\
\hline 1 farm & $155 \%$ increase & $\$ 4.30 /$ gallon & $70 \%$ decline & 4.06 \\
\hline 5 farms & $6 \%$ increase & $\$ 2.49 /$ gallon & $5 \%$ decline & 14.56 \\
\hline \multicolumn{5}{|l|}{ Yogurt } \\
\hline 1 farm & $3 \%$ increase & $\$ 1.80 /$ quart & $2 \%$ decline & 13.26 \\
\hline 5 farms & $2 \%$ decrease & $\$ 1.71 /$ quart & $3 \%$ increase & 14.92 \\
\hline \multicolumn{5}{|l|}{ Cheese } \\
\hline 1 farm & $11 \%$ increase & $\$ 6.11 /$ pound & $11 \%$ decline & 12.04 \\
\hline 5 farms & $5 \%$ decrease & $\$ 4.59 /$ pound & $3 \%$ increase & 14.95 \\
\hline \multicolumn{5}{|l|}{ Base prices } \\
\hline \multicolumn{5}{|l|}{ Fluid milk } \\
\hline 1 farm & & $\$ 2.25 /$ gallon & & 13.53 \\
\hline 5 farms & & $\$ 2.25 /$ gallon & & 15.25 \\
\hline \multicolumn{5}{|l|}{ Yogurt } \\
\hline 1 farm & & $\$ 1.75 /$ quart & & 13.53 \\
\hline 5 farms & & $\$ 1.75 /$ quart & & 14.53 \\
\hline \multicolumn{5}{|l|}{ Cheese } \\
\hline 1 farm & & $\$ 5.50 /$ pound & & 13.53 \\
\hline 5 farms & & $\$ 5.50 /$ pound & & 14.53 \\
\hline
\end{tabular}

related to the potential returns on investment for each plant (Table 11).

The returns on investment for both fluid plants are negative. For the 1-farm fluid milk plant, the present value of revenues over the $10-\mathrm{yr}$ period would have to increase $155 \%$, holding all other things constant, for it to break even. It would require increasing the price the plant receives for processed milk by $\$ 2.05$ per gallon, which would result in a consumer price of nearly $\$ 6.00$ per gallon after retail mark-up. Similarly, the present value of all expenses for this plant over the period would have to decline by $70 \%$ for the plant to break even. A $70 \%$ decline in the expense allocated for raw milk would result in a price to the farmer of only $\$ 4.06 / \mathrm{cwt}$. The 5farm fluid plant would need a $6 \%$ increase in present value of revenues, which translates to a $\$ 0.24$ increase in the price received per gallon of milk sold. Because the 5 -farm fluid plant would purchase milk from other farmers, it would be required to pay into the Federal Milk Marketing Order's Producer Settlement Fund, and as a result, its cost of milk would equal the Class I price, even though farmers are paid according to the SUP formula. To reach the break-even point, this larger fluid plant would need a $5 \%$ decrease in the present value of its expenses, including a decrease in the Class I price to $\$ 14.56 /$ cwt, without showing measurable benefit to the supplying farmers.

The smaller yogurt plant would require a $3 \%$ increase in present value of revenues or a $2 \%$ decline in present value of expenses to break even. The present value received for a quart of yogurt would have to increase $\$ 0.05$, or the price paid for farm milk would have to decline $\$ 0.27$ to $\$ 13.26 / \mathrm{cwt}$ to reach this goal. The analysis indicates that the 5 -farm yogurt plant could withstand a $2 \%$ decline in revenues or a $3 \%$ increase in expenses and still break even. On a present-value basis, the larger plant could receive $\$ 0.04$ less per quart of yogurt, or return $\$ 0.39$ more per hundredweight to farmers and still meet its obligations.

The 1-farm cheese plant would need to increase present value of revenues or decrease present value of expenses by $11 \%$ to break even. The present value for the price of a pound of cheese sold would have to increase by $\$ 0.61$ to raise revenue sufficiently, or the amount returned to the farmer would have to decline by $\$ 1.49$ to $\$ 12.04 /$ cwt to break even. The 5 -farm cheese plant could experience a $5 \%$ decline in present value of revenues or a $3 \%$ rise in present value of expenses before breaking even. Such declines in revenue would mean a $\$ 0.91$ decrease in the received price for a pound of cheese, or an increase in the pay price to farmers of $\$ 0.42 /$ cwt on a present-value basis.

Both the 5-farm yogurt and cheese plants have solid positive returns on investment in the baseline analysis. However, testing the sensitivity of these projections shows that 2 to $5 \%$ declines in the present value of revenues or a $3 \%$ increase in the present value of expenses would eliminate the positive margins. The re- 
sults of this sensitivity analysis are supported by other studies of larger US companies that document that as little as a $1 \%$ change in price can translate to an 8 to $12 \%$ change in profitability, when other factors are controlled (Matanovich et al., 1999; Marn et al., 2003). It is unlikely that the fluid processing plants would be able to overcome the baseline revenue shortfalls or the high level of expenses to reach a break-even point. It is worth noting, however, that relatively small adverse changes in revenues or expenses for the larger yogurt and cheese plants pose significant risks to profitability.

\section{CONCLUSIONS}

This study attempts to estimate the economic feasibility of establishing a small-scale dairy processing plant. In collecting financial data and estimating future income and expense scenarios, the study relies on key assumptions regarding plant ownership, financing, construction costs, management, and marketing skills of owners. Although altering any of the underlying assumptions may yield different results, the study does provide a useful framework for analyzing the feasibility of similar ventures.

Using both NPV and IRR measures of projected profitability, sensitivity analysis is then performed to assess the risk associated with achieving the stated NPV and IRR results by plant size and type. Taken together, the baseline analyses and the sensitivity analysis provide measurements by which results and risk for such investments can be judged.

The findings indicate that the larger capacity yogurt and cheese plants would be the most profitable investment alternatives, followed by the small yogurt plant, which would essentially operate at break-even over the period considered. Neither of the fluid milk plants was profitable. For the small cheese plant to generate sufficient returns on investment to make it viable, an operator must rely on premium pricing strategies for high quality products that are effectively marketed and efficiently distributed.

The very small scale of the plants modeled reduces the amount of dairy products that can be processed and sold, and the limited milk volume results in less efficient utilization of plant capacities. Yogurt production offers the benefits of a shelf-stable product over several weeks. The product can be flavored and frozen to increase differentiation in the marketplace and appeal to multiple consumer preferences. Conversion of 1 pound of milk into 1 pound of yogurt is far more favorable than conversion of 10 pounds of milk into 1 pound of cheese. Furthermore, storing cheese through the aging process may further delay receipt of revenue by several months from the time that the milk is produced. Those seeking to increase income for farmers through value-added processing should take these factors into consideration.

\section{ACKNOWLEDGMENTS}

This study was conducted on behalf of the town of Westfield, Vermont, through a Vermont Community Development Planning Grant [Grant \#0161/98PG(13)] from the Vermont Agency of Commerce and Community Development, for which the authors are thankful. We also gratefully acknowledge the expert wisdom, guidance, and critical feedback from individuals in the New England dairy industry who wished to remain anonymous.

\section{REFERENCES}

Adelman, P. J., and A. M. Marks. 2001. Entrepreneurial Finance for Small Business. 2nd ed. Prentice Hall, New York, NY.

Dunn and Bradstreet. 2002. Industry norms and key business ratios-One year. Dunn and Bradstreet, Inc., New York, NY.

Erba, E. M., R. D. Aplin, and M. W. Stephenson. 1997. Labor productivities and costs in 35 of the best fluid milk plants in the US. Cornell Program on Dairy Markets and Policy. Cornell University, Ithaca, NY.

Federal Milk Market Administrator. 2003. Subject: Monthly pool prices announcements. http://www.fmmone.com/ Accessed July $10,2003$.

Federal Reserve Bank of St. Louis. 2003. Subject: Bank prime loan rate. http://research.stlouisfed.org/fred/data/irates/mprime Accessed July 10, 2003.

Food Processing Center. 2002. Nebraska Specialty Cheese Plant 2002. University of Nebraska-Lincoln, NE.

Hayes, S. L. 2002. Finance for Managers. Harvard Business School Press, Cambridge, MA.

Howick, S. C., G. K. Criner, and S. L. Jacobs. 1993. Milk processing and distribution costs: Maine. Department of Resource Economics and Policy, University of Maine, Orono.

Kohl, D. M. 1992. Weighing the variables: A guide to Ag credit management. American Bankers Association, Washington, DC.

Marn, M. V., E. V. Roegner, and C. C. Zawanda. 2003. The power of pricing. McKinsley Q. 1:27-39.

Matanovich, T., G. L. Lillien, and A. Rangaswamy. 1999. Engineering the price-value relationship. Marketing Management 8(1):48-53.

New England Agricultural Statistics Service (NEAS). 2003. Subject: Annual milk production for 2002. http://www.nass.usda.gov/nh/ Accessed July 12, 2003.

Risk Management Association. 2001. Annual Statement Studies 2000-2001. RMA Information Services, Philadelphia, PA.

US Department of Agriculture. 2004. 2002 Census of Agriculture. USDA, Washington, DC.

US Department of Labor. 2003. Subject: Consumer Price Index. http:// www.bls.gov/cpi/home.htm Accessed July 10, 2003.

Vermont Department of Employment and Training. 2003. Subject: Vermont labor market information. http://www.vtlmi.info/occupation.cfm Accessed July 10, 2003.

Waier, P. R. 2002. RS Means Building Construction Cost Data. 60th ed. RS Means Company, Inc., Kingston, MA. 


\section{APPENDIX}

Table A1. Itemized listing of plant equipment cost prices

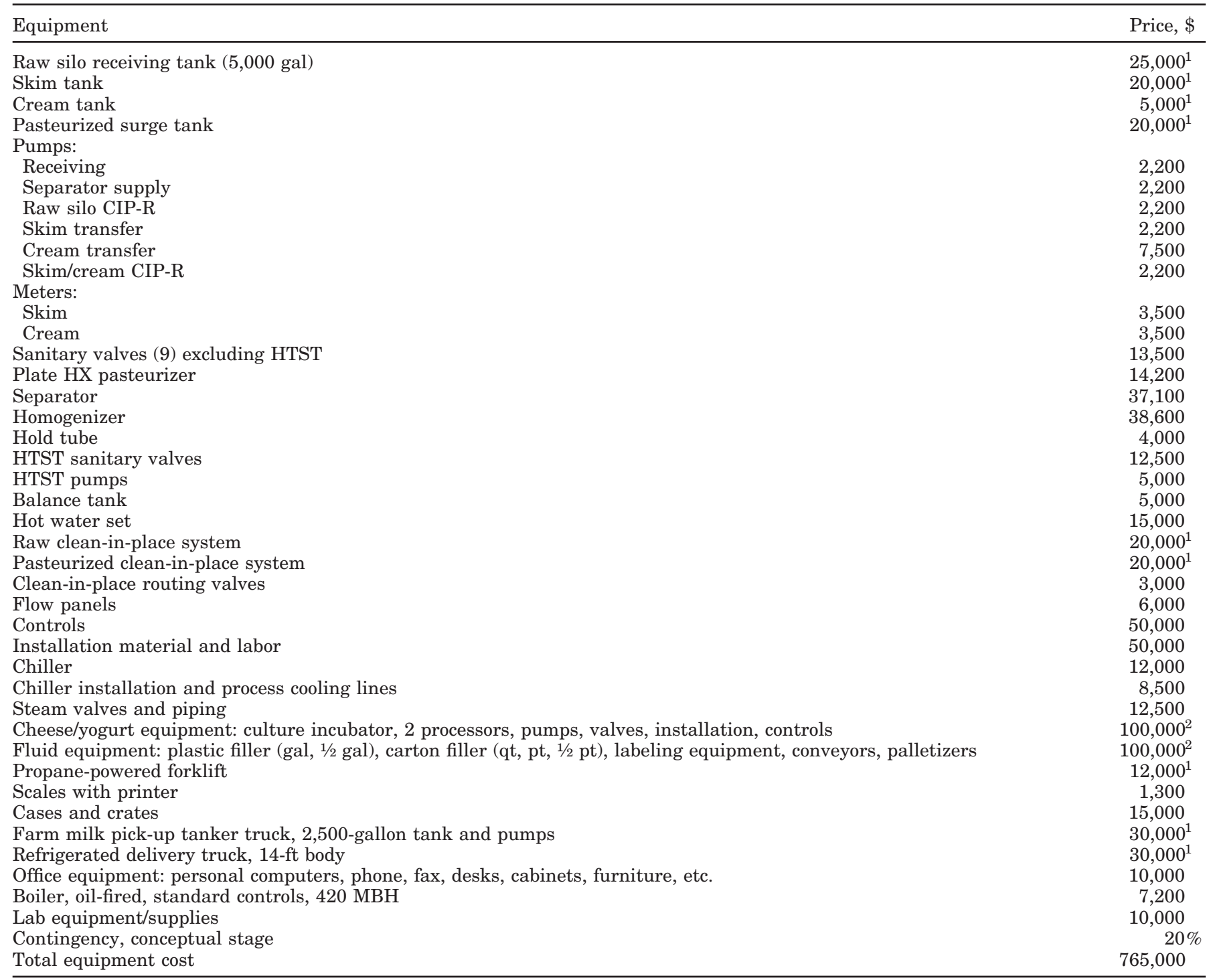

${ }^{1}$ Used price.

${ }^{2}$ Estimated prices for aggregate processing setups.

Table A2. Net present value data and calculations over a 10-yr period

\begin{tabular}{|c|c|c|c|c|c|c|}
\hline \multirow[b]{3}{*}{ Year } & \multicolumn{6}{|c|}{ Annual net cash flow, $\$$} \\
\hline & \multicolumn{2}{|c|}{ Fluid plant } & \multicolumn{2}{|c|}{ Yogurt plant } & \multicolumn{2}{|c|}{ Cheese plant } \\
\hline & 1 farm & 5 farms & 1 farm & 5 farms & 1 farm & 5 farms \\
\hline Initial investment & $(1,280,000)$ & $(1,780,000)$ & $(1,280,000)$ & $(1,780,000)$ & $(1,280,000)$ & $(1,780,000)$ \\
\hline 1 & $(222,052)$ & $(462,255)$ & $(109,857)$ & $(224,421)$ & $(171,885)$ & $(97,403)$ \\
\hline 2 & $(225,252)$ & $(413,667)$ & $(61,070)$ & $(131,904)$ & $(122,279)$ & $(1,096)$ \\
\hline 3 & $(228,114)$ & $(348,261)$ & (787) & $(8,373)$ & $(61,804)$ & 92,008 \\
\hline 4 & $(230,439)$ & $(262,054)$ & 54,279 & 114,902 & 8,664 & 211,254 \\
\hline 5 & $(231,974)$ & $(150,215)$ & 121,382 & 271,463 & 75,123 & 232,436 \\
\hline 6 & $(232,398)$ & $(5,178)$ & 202,883 & 471,720 & 155,124 & 400,894 \\
\hline 7 & $(231,305)$ & 131,201 & 301,591 & 725,761 & 251,138 & 613,878 \\
\hline
\end{tabular}


Table A2 (Continued). Net present value data and calculations over a 10-yr period

\begin{tabular}{|c|c|c|c|c|c|c|}
\hline \multirow[b]{3}{*}{ Year } & \multicolumn{6}{|c|}{ Annual net cash flow, $\$$} \\
\hline & \multicolumn{2}{|c|}{ Fluid plant } & \multicolumn{2}{|c|}{ Yogurt plant } & \multicolumn{2}{|c|}{ Cheese plant } \\
\hline & 1 farm & 5 farms & 1 farm & 5 farms & 1 farm & 5 farms \\
\hline 8 & $(228,184)$ & 302,860 & 420,844 & $1,045,802$ & 366,081 & 881,437 \\
\hline 9 & $(222,401)$ & 517,487 & 564,608 & $1,446,610$ & 503,386 & $1,215,715$ \\
\hline 10 & $(213,165)$ & 784,333 & 737,595 & $1,946,010$ & 667,094 & $1,631,362$ \\
\hline Discount rate, $\%$ & 8.0 & & & & & \\
\hline Net present value, $\$$ & $(2,801,750)$ & $(2,274,891)$ & $(156,906)$ & $1,072,476$ & $(532,668)$ & 966,214 \\
\hline Internal return rate, $\%$ & $\mathrm{NMF}^{1}$ & -8.3 & 6.4 & 13.8 & 2.7 & 13.9 \\
\hline
\end{tabular}

${ }^{1} \mathrm{NMF}=$ no meaningful figure.

Table A3. Federal Milk Marketing Order No. 1 producer milk minimum class prices in the Northeast marketing area by class from January 2000 to May $2003^{1}$

\begin{tabular}{|c|c|c|c|c|}
\hline \multirow[b]{2}{*}{ Month } & \multicolumn{4}{|c|}{ Price, $\$$} \\
\hline & Class I & Class II & Class III & $\begin{array}{c}\text { Statistical } \\
\text { uniform price }\end{array}$ \\
\hline January 2000 & 14.15 & 11.43 & 10.05 & 12.35 \\
\hline February 2000 & 13.96 & 11.51 & 9.54 & 12.21 \\
\hline March 2000 & 14.09 & 11.71 & 9.54 & 12.39 \\
\hline April 2000 & 14.18 & 12.10 & 9.41 & 12.46 \\
\hline May 2000 & 14.73 & 12.63 & 9.37 & 12.90 \\
\hline June 2000 & 14.95 & 13.08 & 9.46 & 13.25 \\
\hline July 2000 & 15.71 & 12.58 & 10.66 & 13.52 \\
\hline August 2000 & 15.20 & 12.56 & 10.13 & 13.39 \\
\hline September 2000 & 15.09 & 12.58 & 10.76 & 13.63 \\
\hline October 2000 & 15.14 & 12.54 & 10.02 & 13.32 \\
\hline November 2000 & 15.07 & 13.68 & 8.57 & 13.36 \\
\hline December 2000 & 15.38 & 13.97 & 9.37 & 13.72 \\
\hline January 2001 & 17.24 & 12.82 & 9.99 & 13.76 \\
\hline February 2001 & 15.19 & 13.43 & 10.27 & 13.62 \\
\hline March 2001 & 15.90 & 14.17 & 11.42 & 14.50 \\
\hline April 2001 & 16.69 & 15.10 & 12.06 & 15.24 \\
\hline May 2001 & 17.46 & 15.72 & 13.83 & 16.32 \\
\hline June 2001 & 18.24 & 16.05 & 15.02 & 17.08 \\
\hline July 2001 & 18.59 & 15.96 & 15.46 & 17.21 \\
\hline August 2001 & 18.65 & 15.98 & 15.55 & 17.53 \\
\hline September 2001 & 18.81 & 16.24 & 15.90 & 17.76 \\
\hline October 2001 & 19.18 & 13.53 & 14.60 & 16.04 \\
\hline November 2001 & 19.01 & 12.78 & 11.31 & 15.28 \\
\hline December 2001 & 15.23 & 12.61 & 11.80 & 13.72 \\
\hline January 2002 & 15.21 & 12.69 & 11.87 & 13.81 \\
\hline February 2002 & 15.20 & 12.28 & 11.63 & 13.48 \\
\hline March 2002 & 14.87 & 12.19 & 10.65 & 13.05 \\
\hline April 2002 & 14.72 & 11.88 & 10.85 & 12.94 \\
\hline May 2002 & 14.51 & 11.29 & 10.82 & 12.63 \\
\hline June 2002 & 14.28 & 11.19 & 10.09 & 12.38 \\
\hline July 2002 & 13.87 & 11.14 & 9.33 & 12.05 \\
\hline August 2002 & 13.73 & 11.07 & 9.54 & 12.16 \\
\hline September 2002 & 13.71 & 10.91 & 9.92 & 12.20 \\
\hline October 2002 & 13.40 & 11.12 & 10.72 & 12.40 \\
\hline November 2002 & 13.85 & 11.26 & 9.84 & 12.31 \\
\hline December 2002 & 13.77 & 11.62 & 9.74 & 12.24 \\
\hline January 2003 & 13.81 & 11.29 & 9.78 & 12.19 \\
\hline February 2003 & 13.48 & 10.66 & 9.66 & 11.79 \\
\hline March 2003 & 13.06 & 10.54 & 9.11 & 11.43 \\
\hline April 2003 & 12.89 & 10.44 & 9.41 & 11.45 \\
\hline May 2003 & 12.96 & 10.43 & 9.71 & 11.60 \\
\hline Mean class price & 15.25 & 12.60 & 10.90 & 13.53 \\
\hline
\end{tabular}

${ }^{1}$ USDA/Marketing Service; Northeast Marketing Area; Federal Order 1; http://www.fmmone.com/. 